\title{
Digital tools for determining the cadastral valuation for the sustainable development of the region
}

\author{
Sergey Sternik ${ }^{1,2, *}$, Ilnur Gareev ${ }^{3}$, and Timur Akhmetgaliev ${ }^{3}$ \\ ${ }^{1}$ Institute of Economic Forecasting of Russian Academy of Sciences, Moscow, Russia \\ ${ }^{2}$ Moscow State University of Civil Engineering (National Research University), Moscow, Russia \\ ${ }^{3}$ Kazan State University of Architecture and Engineering, Kazan, Russia
}

\begin{abstract}
This article studies digital information databases and aggregators of the real estate market as tools for the correct determination of the real estate cadastral value for the purpose of sustainable development of regions. An overview of foreign studies and software products in the framework of determining the real estate cadastral value of objects is presented. The author shows the statistics of challenging the cadastral value in Russia, including a specific example, as well as analyzed the reports on the determination of the cadastral value for the presence of the use of information databases and aggregators of the real estate market. As a result of the study, the author's ideas for filling and using the information database of real estate objects were proposed in order to correctly determine the real estate cadastral value of objects.
\end{abstract}

\section{Introduction}

The priority direction of the new stage of economic changes is the innovative modernization of the economy of the regions of Russia, the problems of focusing on creating conditions for sustainable development of the region, enhancing innovation, improving the structure of the regional economy [8] come to the fore today. One of the indicators of sustainable development of the region is the level of development of residential and commercial real estate construction. The main factor for sustainable development is such a financial and economic factor as the stability of the region's budget. A component of this budget is property tax, which is determined from the real estate cadastral value objects. Thus, there is an interdependence of the sustainable development of the region on the level of prices for real estate in the region.

The methodology for assessing the cadastral value in most developed countries is developed at a certain level, there is a transparent system for all stakeholders and users. In Russia, the state cadastral valuation of land has been carried out since 1999. As of 2015, the cadastral valuation of all categories of land was carried out at least twice; in most constituent entities of the Russian Federation, the cadastral value was updated three times. In 2011-2012, the cadastral appraisal of capital construction objects was carried out for the first time in all

\footnotetext{
* Corresponding author: sergey-sternik@yandex.ru
} 
constituent entities of the Russian Federation [7]. However, in Russia, when determining the cadastral value and accepting the calculation data for the approval of the value from which the tax is calculated, there is a significant number of problems. The results of determining the cadastral value raise a number of questions for taxpayers, including the problem of VAT accounting. For instance, in the report on the RT, when determining the market value as of $01 / 01 / 2014$, it is indicated that the value was determined without VAT, however, in some court materials, this is interpreted ambiguously, thereby comparing the value without VAT with the value with VAT. The dispute on the inclusion or non-inclusion of VAT in the market value has no theoretical solution and can only be resolved by including a special provision in the standards (federal or standards of a self-regulatory organization of appraisers) [1].

There is no analysis of previous cadastral and market estimates for cadastral numbers, including analysis for disputed objects. It turns out that if the interested party contested the cadastral value at the date of determining the cadastral value for one amount, then the new cadastral valuation does not consider the results of the contested value, but uses the results of the previous cadastral valuation with a slight amendment on the date, which is an infringement of property rights.

An obstacle in establishing the cadastral value in the amount of the market value is also the bureaucratic and corruption component [16]. A number of interested parties in order to prevent the dispute of the cadastral value are trying in all possible ways not to allow the value of the object to be disputed, motivating completely unfounded comments on the reports on determining the market value of the disputed real estate objects. With a large flow of materials of cases on an overestimated cadastral valuation, there is real estate, which, on the contrary, is at times underestimated, e.g., a market segment in housing construction. Pursuant to analysts, in the second half of last year (2020), prices on the primary real estate market jumped in some cases by $40 \%$ [10], and the last cadastral assessment for this type of property was carried out as of 01/01/2014. As the tax period for real estate tax, it would be reasonable to set not one date of the calendar year - January 1, but the whole year. The beginning of the year should be considered the beginning of the tax period, and, therefore, the cadastral value should be established as of the beginning of the tax period [12]. A limited information sample, namely an irrelevant and incomplete database on real estate objects, leads to incorrect conclusions and results in determining the real estate cadastral value objects [15]. The cadastral appraisal should be performed by teams of professionals, including highly qualified specialists in various fields - from highly qualified analysts of the real estate market and computer modelers to appraisers with extensive experience [4].

In order to ensure the sustainable development of the region and the correct determination of the cadastral value, we analyze the existing information databases of the real estate market and develop a single information resource about land and real estate objects. With the help of this resource, it will be possible to show the relationship between prices for residential and commercial real estate for a certain period in the context of time and territorial location, to obtain the dependence of the introduced residential and commercial real estate in the regions of Russia.

\section{Research methods}

The purpose of this work is to study information databases of real estate objects in determining the cadastral value in the framework of sustainable development of the regions of Russia.

The main tasks for achieving the goal are:

- investigate foreign research in the framework of determining the real estate cadastral value objects;

- show statistics of challenging the cadastral value in Russia; 
- display a structural and consistent assessment over a specific period using a specific example;

- analyze the completed reports on the determination of the cadastral value for the use of information databases and aggregators of the real estate market

- propose author's ideas for the use and filling of a unified information database of real estate objects.

\section{Results of the study}

The process of real estate taxation has existed abroad for many years. There, the methodology for determining the appraised value is based either on a comparison of sales, i.e. on the study of the prices of market transactions with real estate objects (for land plots - Australia, Denmark, Sweden, Indonesia, and Japan), or on the capitalization of income from the potential best and most profitable use of real estate (for individual real estate objects - some cantons of Switzerland, Denmark, Sweden), or a cost approach is used to determine the assessed value, i.e. the costs that would be required for the complete restoration of the real estate object are calculated (for buildings - Indonesia, Japan, South Korea), or all three methods are combined (USA, Canada, Netherlands) [9].

The inventory data covers the entire country in Finland, although some known inaccuracies exist, such as in the location information. Therefore, improving the quality of registration data with currently available technologies is not seen as a priority in the coming decades, as the focus is on the complexity of possible new correct usage decisions. In addition, it can be argued that the development of automation also extends to the collection of cadastral information [19].

Cadastral data related to land use are crucial in the process of real estate management, including the calculation of taxes. Their unreliability can lead to the loss of financial resources by local governments. Due to differences in actual circumstances on the ground, as well as negligence on the part of owners when submitting applications for data updates, it becomes necessary to regularly check and update the register. In Poland, in many cases, cadastral data are updated too infrequently, including to obtain information. Moreover, there is no detailed regulation for checking such data. Meanwhile, modern geodetic and photogrammetric instruments can allow their use in the maintenance of the cadaster in Poland, including the regular verification of the data entered in the register, which is confirmed by technical and precise capabilities. Aerial photographs obtained from manned or unmanned aerial vehicles have enormous information potential, which is also objective evidence [13].

The LADM_VM software product is aimed at clarifying the characteristics and semantics of appraisal registers held by government agencies, as well as identifying the relationship between appraisal registers and other land administration registers, such as the cadaster, the register of buildings and dwellings, etc.

LADM_VM is a conceptual diagram. Its implementation allows the accounting of data concerning the objects of valuation (i.e., units of valuation), the parties involved in the practice of valuation, inputs and outputs used and produced in the framework of single or bulk valuation processes, transaction prices and sales statistics. The development of an information model for appraisal and appraisal of real estate for periodic tax purposes is the initial goal, but it has the potential to represent other valuation purposes. 


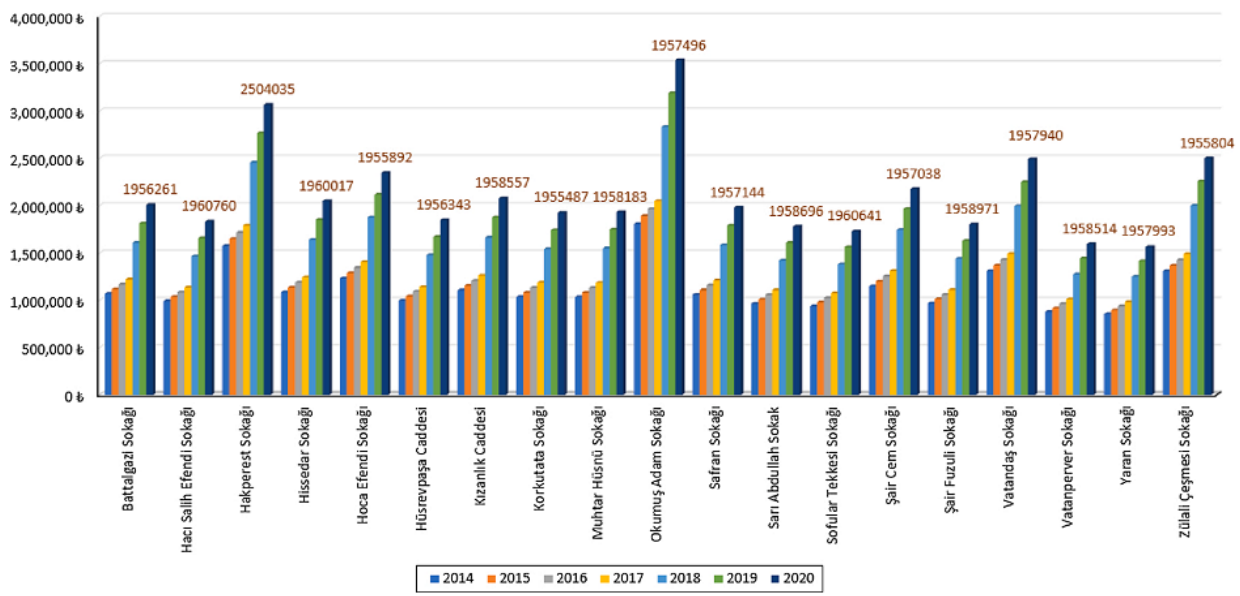

Fig. 1. Time series of tax values of real estate objects with similar characteristics on different streets (e.g., housing construction).

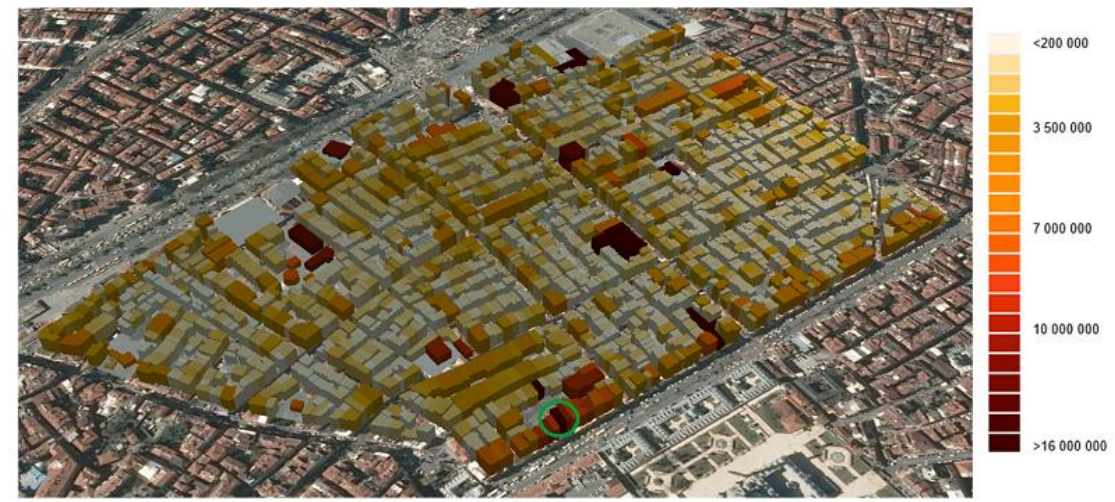

Fig. 2. Buildings are painted pursuant to the 2020 tax value of real estate (example of housing construction).

In this study, a real database implementation was used to assess the feasibility of the technical implementation of the Country Profile based on a series of queries. The overall assessment of the efficiency of the database implementation is satisfactory and encouraging. Considering the appraisal, it can be concluded that both LADM_VM and its Turkish Country Profile can be considered feasible in terms of managing and requesting information related to real estate appraisal. On the other hand, various aspects of LADM_VM need to be further tested in future implementations. For instance, part of a mass appraisal model should be assessed using a comprehensive and detailed dataset that includes mass appraisal performance indicators. The scope of the model is not limited to estimates, it can also provide transaction prices and sales statistics. A future implementation of LADM_VM may include sales statistics using time series of transaction prices [18].

In the first version of LADM, property values are considered out of scope, but LADM does provide a solid and flexible basis for property valuation. The closely related LADM extensions were used to create a prototype for the Croatian mass real estate appraisal system. These extensions are the Assessment Information Model Package (formerly known as the LADM valuation/taxation fiscal extension) and the Spatial Planning Information Package. 
The LADM Appraisal Information Model deals with dataset management in relation to real estate appraisal and taxation [22].

Researchers in the United States use new, very fine (ie, high spatial-temporal resolution) microdata to construct most of the bottom-up aggregate estimates. They use microdata from Zillow, in particular, their Zillow Transaction and Estimation Dataset (ZTRAX) dataset that was recently made available to researchers in academia and government. This resource contains data on market transactions, as well as a large set of individual characteristics of real estate for sales, reflected in the data of the local tax appraiser.

The USA national market, initially with 374 million detailed transaction records in over 2,750 counties $(91.5 \%$ of US counties). Not all US states require disclosure of sales prices, so while the data cover most of the country, the price data, in particular, has some limitations in coverage, especially for the 13 (mostly rural) states. This dataset contains the most detailed information on the residential housing market compared to other land uses, but residential land usually represents the highest aggregate land value for most countries. Specifically, this data includes details of the sale price of each home, the date of sale, mortgage information, foreclosure status, and other information typically disclosed by the local tax officer for each real estate transaction.

Scientists link each transaction to the characteristics of each property into a single dataset that can then be used for hedonic modeling (which statistically determines the effect of specific property characteristics on property value) [17]. These estimates include a set of characteristics found on the Zillow website or local tax assessor's office that describe the property: size of building per lot (square feet), size of lot (acres), number of rooms, bedrooms, and bathrooms, year buildings and various other characteristics. In addition to residential properties, Zillow data includes sales of commercial, industrial, agricultural, and other properties, as well as vacant land.

One of the most important aspects of this data is that there is detailed information about the location of each property (address and latitude/longitude) such that this fine-level spatial data can be associated with any level of geography, which is useful for several reasons. First, property-level data can be linked to LULC, allowing direct integration of data sources. Second, a key aspect of the valuation is the location itself, which includes local amenities that can be relevant to buyers/sellers and built into the valuation model. Third, the scientists' model evaluates each object individually, allows aggregation at any level of geography (provided that there are enough observations within a specific area, which provides a reasonable estimate). Thus, these data allow to construct estimates "from the bottom up" [23].

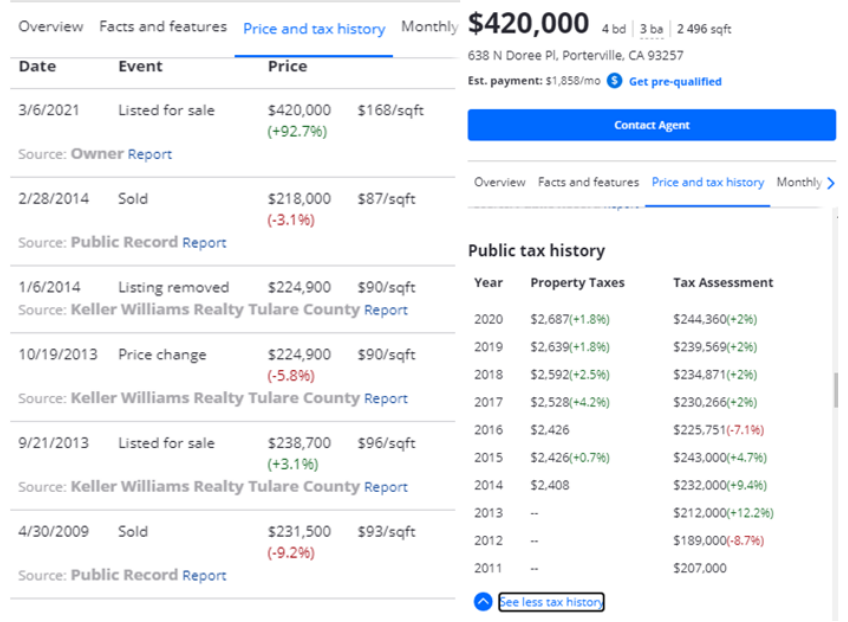

Fig. 3. Example of an ad from the website https://www.zillow.com/ [21]. 
Pursuant to the above website, it can be seen that this information base of US real estate objects displays not only the market price of the offer (e.g., a residential building), but also displays information about the cost in the context of time, namely since 2009 , where the cost of selling a home was $\$ 231,500$ through 2021 with price changes. A feature of this service is the section "Public tax history", which provides information from 2013 to 2020. Pursuant to Fig. 3 in the period from 2009 to 2014, there are no significant differences between the market and cadastral values, which, pursuant to the author, should correspond to reality. From 2014 to 2020, the tax value changed depending on the price fluctuation in the market in the corresponding segment. The latest offer price is 420,000 USD for 2021, possibly due to the major renovation of the house. Accordingly, when determining the tax base in the United States, the tax inspector should pay attention to this and consider when calculating the tax. The big plus of the above product is the openness and transparency of data, which allows to determine the tax (cadastral) value pursuant to the market [14].

In Russia, as a result of court decisions on claims filed in courts in the period from $01 / 01 / 2020$ to $12 / 31 / 2020$, there is a drop in the total value of the cadastral value in relation to real estate objects, on which decisions were made, as of $12 / 31 / 2020$ approximately by 228.6 bln roubles $(52 \%)$ :

- the total value of the cadastral value before the challenge was about 441.68 bln roubles;

- after contestation - about 213.06 bln roubles [3].

In most cases, when applications for revising the cadastral value are rejected, the reason for the refusal is that the report does not comply with Article 11 of the Federal Law of July 29, 1998, No. 135-FZ "On appraisal activities in the Russian Federation", the requirements for the content of appraisal reports, to the description in the assessment report of the information used in the assessment, established by federal valuation standards, which is expressed in the fact that the report does not comply with the principle of unambiguity. Some reports may be "rejected" even at the stage of accepting applications due to incorrectly applied methodology, e.g., the exclusion of VAT from the market value of a capital construction project [11].

For instance, pursuant to the results of the state cadastral valuation of land, the cadastral value of a land plot with cadastral number 16:51:010401:83 as of 01/01/2010 was $6,396,479.58$ roubles. [5]. This cadastral value was contested in the period from 2010 to 2011 and amounted to 2,350,000 roubles pursuant to the company "N". However, the person concerned again applied for the services of challenging the cadastral value, where, pursuant to the new report, the cadastral value was $6,631,273.98$ roubles. [2]. As a result, the cadastral value was re-contested on a new date - 01/01/2015, where, pursuant to https://pkk.rosreestr.ru/, the contested cadastral value was 3,220,842 roubles.

The author of the article analyzed the following reports on the assessment of the cadastral value:

- Report No. 1 on the determination of the cadastral value of land plots within the land of the settlement of Kazan as of 01/01/2013;

- Report No. 2 on determining the cadastral value of land plots of horticultural, vegetable gardening, and dacha associations of the Republic of Tatarstan outside the boundaries of settlements as of $01 / 01 / 2013$;

- Report No. 2 on the determination of the cadastral value of the residential and nonresidential real estate (excluding land plots) located on the territory of the Republic of Tatarstan as of $01 / 01 / 2014$

- Report No. 1 on the determination of the cadastral value of land plots as part of industrial and other special-purpose lands (outside settlements) located on the territory of the Republic of Tatarstan as of 01/01/2014.

When executing the above reports, the main initial data were the data of the main aggregators of the real estate market: 
1. Dashboard «AVITO»;

2. Dashboard "KAZAN.IRR.RU";

3. Dashboard "KAZAN.OLX.RU";

4. Dashboard "AVITO";

5. Dashboard "KAZAN.IRR.RU";

6. Dashboard "KAZAN.OLX.RU";

7. Dashboard "KAZAN.TAT.SLANDO.RU";

8. Dashboard "KAZAN.IRR.RU";

9. Dashboard "PRONTO-MEDIA.RU";

10. Dashboard "ROSREALT.RU";

11. Dashboard "TATRE.RU";

12. Data of the Office of the Russian Register for the Republic of Tatarstan (in the form of information on concluded transactions);

As a result, it was revealed that aggregators of the real estate market are mainly used. The use of informational database and systems, with the exception of partial information of the Rosregister database, is absent.

\section{Discussion of the results}

Pursuant to the author's research, the following databases can be distinguished on the real estate information database market:

1. Krona software package;

2. Mobile appraiser;

3. National Unified Base of Objects (NEBO);

4. "Announcement archive" (https://ruads.org/);

5. "Archive Appraiser.rf";

6. Reliable information portal (PDI - dostinfo.ru).

The above resources collect in an automated form information about real estate objects presented on the main market aggregators, where the number of sources is from 80 and more. There are auto-collected ads from various sources, as well as deduplication of data and other information on objects.

Additionally, one of the sources for filling the unified information base can be federal resources for auctions, auctions, pledges, objects related to bankruptcy and other information platforms for real estate objects:

1. The official website of the Russian Federation on the placement of information about the bidding - http://torgi.gov.ru;

2. Section "Realization and disposal of property" on the website of the Federal Agency for State Property Management - www.rosim.ru/activities/realization;

3. Section "Lease of Federal Property" on the website of the Federal Agency for State Property Management - www.rosim.ru/activities/rent;

4.Unified Federal Register of Bankruptcy Information, section "Trades" http://bankrot.fedresurs.ru/TradeList.aspx;

5. Russian portal of pledged property - www.zalog24.ru;

6. Electronic trading platform "Fabrikant" - https://www.fabrikant.ru/;

7.Official site of JSC "Russian Railways", section "Real estate transactions" http://property.rzd.ru;

8. Systematized information on the most liquid objects sold during auction procedures and during direct sales - www.sold-online.ru;

9. A marketplace for placing free advertisements of individuals and legal entities for the purchase or sale of debts and ready-made firms - https://debbet.ru/ [7]. 
The author of this article is developing technical specifications for the digital platform "KVADU.RU". This platform will present an information product for conducting transactions with real estate, considering, among other things, the collection and processing of data on real estate.

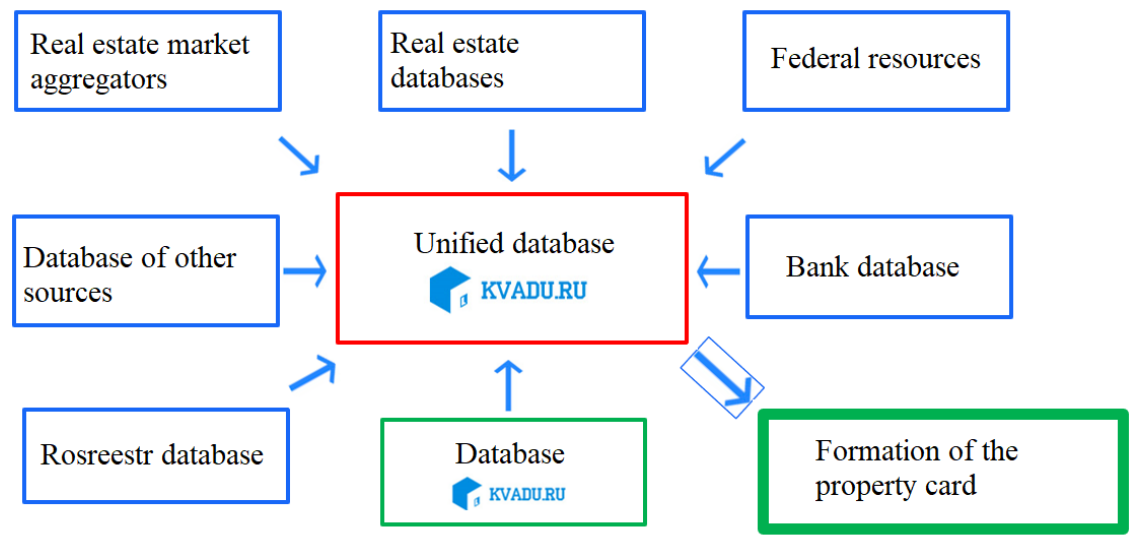

Fig. 4. Unified database of real estate objects (compiled by the author)

Pursuant to the possible sources of information used, if there is a technical feasibility, the product being developed will be able to collect and structure information on real estate objects from various sources.

An exclusive feature of the product being developed is data synchronization using GIS in the context of the author's dynamic classification of real estate objects. This classification is aimed at responding to price changes in the relevant segment, in determining the cadastral value. It is used to move from an individual variety of real estate objects to a limited number of classes of objects of assessment. The basis of the classification is the different functional purpose (use) of the objects of appraisal, which determines the difference in value [6].

Based on the analyzed products and data, pursuant to the author, the most optimal model for determining the cadastral value is a dynamic model in a semi-automated form. One of the functions of this product will be to determine the real estate cadastral value for various valuation dates [20].

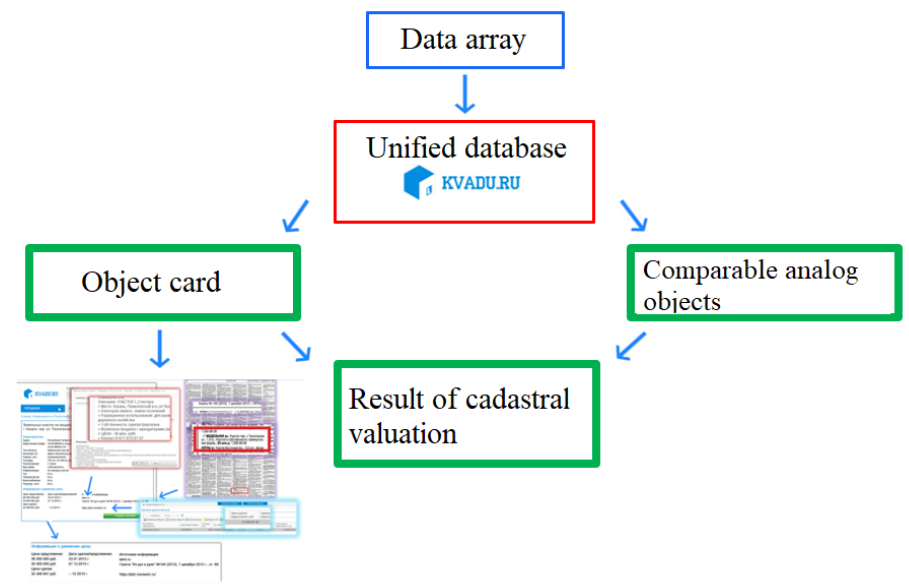

Fig. 5. Determination of the cadastral value using the KVADU.RU database (source: compiled by the author). 


\section{Conclusions}

Pursuant to the results of the study, it was revealed that the main software products, when determining the cadastral valuation in foreign countries, are LADM (Turkey) and Zillow (USA). The LADM Valuation Information Model deals with the management of datasets in relation to real estate valuation and taxation. Zillow contains data on market transactions, as well as a large set of individual characteristics of real estate for sale, reflected in the data of the local tax assessor.

For a number of other countries, information is available in the form of accumulated data on real estate objects, however, e.g., in Poland, in many cases, cadastral data are updated too rarely. As for the information bases of real estate objects in Russia, information from aggregators of the real estate market is mainly used. The use of "low-quality" or "garbage" information in determining the real estate cadastral value objects leads to an incorrect determination of the cadastral value, and then to a large number of challenging this value and a decrease in the collection of regional budgets annually.

As a result of court decisions on claims filed in courts in the period from 01/01/2020 to $12 / 31 / 2020$, there is a decrease in the total value of the cadastral value in relation to real estate objects, on which decisions were made, as of $12 / 31 / 2020$ by approximately 228.6 bln roubles $(52 \%)$. This factor is essential in determining the sustainable development of the region and the country as a whole.

To solve this problem, the author of this article proposes to use digital information databases and aggregators of the real estate market as tools for the correct determination of the real estate cadastral value for the purpose of sustainable development of regions. With the correct use of these resources and synchronous interaction of participants in the real estate market, as well as property owners and tax authorities, in the author's opinion, it will be possible not only to correctly determine the cadastral value, but also to increase the collection rate in regional budgets due, on the contrary, undervalued real estate in section in time for a certain period. It will be possible to regularly perform this procedure for a period of at least 1 time per year, as well as track changes depending on the market situation.

\section{References}

1. L.A. Bastrigina, S.V. Shorin, Property relations in the Russian Federation 5 (200), 57 (2018)

2. Official site of the Ministry of Land and Property Relations of the Republic of Tatarstan. https://mzio.tatarstan.ru

3. Official website of Rosreestr. https://rosreestr.gov.ru

4. A.V. Kaminskiy, Property relations in the Russian Federation 2 (173), 6 (2016)

5. M.O. Podprugin, Russian Entrepreneurship 24 (222), 214 (2012)

6. A.V. Pylaeva, Property relations in the Russian Federation 10 (121), 69 (2011)

7. A.V. Pylaeva, Property relations in the Russian Federation 11 (170), 13 (2015)

8. Official site of Rosreestr. https://rosreestr.tatarstan.ru

9. V.N. Reshetnik, Property relations in the Russian Federation 12 (135), 25 (2012)

10. Official website of the Realnoe Vremya portal. https://realnoevremya.ru

11. Official site of the SRG company. https://www.srgroup.ru

12. V.A. Shogin, Property relations in the Russian Federation 7 (166), 61 (2015)

13. A. Cienciała, K. Sobolewska-Mikulska, Land Use Policy 102, 105204 (2021). doi.org/10.1016/j.landusepol.2020.105204;9 
14. L. Droj, G. Droj, Procedia Economics and Finance, 32, 826 (2015). doi.org/10.1016/S2212-5671(15)01525-7

15. E. Essi, L.Teemu, Regional Science and Urban Economics 53, 74 (2015). doi.org/10.1016/j.regsciurbeco.2015.05.006

16. M. Gkeli, Ch. Potsiou, Ch. Ioannidis, Land Use Policy 98, 104419 (2020). doi.org/10.1016/j.landusepol.2019.104419

17. D. Grant, S. Enemark, J. Zevenbergen, D. Mitchell, G. McCamley, Land Use Policy 97, 104758 (2020). doi.org/10.1016/j.landusepol.2020.104758

18. A. Kara, V. Çagdas , U. Isikdag, P. van Oosterom, Ch. Lemmen, E. Stubkjaer, Land Use Policy 104 (2021). doi.org/10.1016/j.landusepol.2021.105307;10

19. P. Krigsholm, K. Riekkinen, P. Ståhle, Land Use Policy 94 (2020). doi.org/10.1016/j.landusepol.2020.104504

20. Q. Lin, M. Kalantari, A. Rajabifard, J. Li, Land Use Policy 45, 8 (2015). doi.org/10.1016/j.landusepol.2015.01.017

21. Official site of the ZILLOW company. https://www.zillow.com

22. T. Hrvoje, M. Ivic Sinisa, R. Miodrag, S. Josip, Land Use Policy 104, (2021) doi.org/10.1016/j.landusepol.2021.105368;11

23. S. A. Wentland, Z. H. Ancona, K. J. Bagstad, J. Boydc, J. L. Hass, M. Gindelskya, J. G. Moulton, Ecosystem Services 46 (2020). doi.org/10.1016/j.ecoser.2020.101178;12 